\title{
PENGARUH SUPLEMENTASI KOMBINASI FE, ASAM FOLAT DAN VITAMIN B 12 TERHADAP PENINGKATAN KADAR HEMOGLOBIN PADA IBU POSTPARTUM DI KOTA PEMATANGSIANTAR
}

\author{
Zuraidah $^{1}$, Sukaisi $^{2}$, Lenny Nainggolan ${ }^{3}$ \\ Program Studi Kebidanan Pematangsiantar Poltekkes Kemenkes Medan
}

\begin{abstract}
Abstrak
Anemia juga berhubungan secara independen mengakibatkan kematian dan kesakitan pada populasi umum. Anemia diidentifikasi dan memberikan bukti bahwa manajemen anemia, terlepas dari faktor resiko lain, meningkatkan angka kematian. Angka kejadian anemia pada postpartum atau masa nifas tertinggi pada negara berkembang. Di Indonesia, belum ada data resmi angka anemia pada ibu postpartum. Tujuan penelitian ini adalah melihat pengaruh suplementasi Fe, asam folat, dan vitamin B12 terhadap peningkatan kadar hemoglobin $(\mathrm{Hb})$ pada ibu postpartum di BPM Kota Pematangsiantar dan sekitarnya. Penelitian ini penelitian quasi eksperimental. Dilakukan pretest yaitu pemeriksaan kadar $\mathrm{Hb}$ awal sebelum suplementasi dan posttest pemeriksaan kadar $\mathrm{Hb}$ akhir setelah suplementasi. Responden penelitian ini ibu postpartum hari keempat berjumlah 40 orang, mengalami anemia dan tanpa penyulit persalinan. Responden dibagi dua kelompok, yaitu ibu postpartum anemia yang diberi suplementasi Fe dikombinasi Asam Folat dan vitamin B12 dan kelompok suplementasi Fe saja. Pemeriksaan Hb dengan metode digital, alat Quick Cek. Hasil penelitian diperoleh ada kenaikkan kadar $\mathrm{Hb}$ pada kedua kelompok ibu postpartum anemia, namun kenaikkan lebih signifikan pada kelompok suplementasi Fe, dikombinasi Asam Folat, dan vitamin B12. Asupan makanan berkorelasi dengan peningkatan kadar $\mathrm{Hb}$ pada kelompok suplementasi kombinasi. Asupan makanan dikaji lebih rinci mengingat ibu postpartum dengan budaya dan kebiasaan keluarga minum teh.
\end{abstract}

Kata kunci : Ibu postpartum, anemia, suplementasi Fe, kombinasi

\section{Pendahuluan}

Anemia merupakan salah satu penyakit paling umum di dunia, yang mempengaruhi $24,8 \%$ dari populasi manusia (1,62 miliar orang) dan merupakan problem kesehatan yang cukup memprihatinkan (Breymann, 2011). Anemia juga berhubungan secara independen mengakibatkan kematian dan kesakitan pada populasi umum. Anemia juga diidentifikasi dan memberikan bukti bahwa manajemen anemia, terlepas dari faktor resiko lain, meningkatkan angka kematian (Habib, 2012).

Angka kematian ibu mengacu pada definisi kematian pada wanita selama masa kehamilan, persalinan, dan 42 hari periode postpartum dari sebab apapun yang terkait dengan atau diperburuk oleh kondisinya (Berhan, 2014). Anemia merupakan kondisi yang umum di seluruh dunia.

Angka kejadian anemia pada postpartum atau masa nifas tertinggi pada negara berkembang (de Benoist, 2008; Berhan 2014), dengan angka prevalensi sekitar 50$80 \%$ (Milman, 2011). Pada negara berkembang, anemia merupakan penyebab utama untuk angka kesakitan dan kematian ibu. Diperkirakan sekitar 500.000 kematian ibu terjadi setiap tahun secara global di dunia berhubungan dengan kelahiran, 20\% diantaranya terjadi karena perdarahan masa persalinan dan anemia (Milman, 2012).
Anemia pada masa postpartum atau nifas didiagnosa dengan kadar hemoglobin $<11 \mathrm{~g} / \mathrm{L}$ pada 1 minggu pascapersalinan dan $<12 \mathrm{~g} / \mathrm{L}$ pada 8 minggu pascapersalinan (Milman, 2011). Penyebab utama anemia masa nifas adalah anemia masa prepartum yang dikombinasikan dengan anemia perdarahan akut karena kehilangan darah saat melahirkan. Selama masa persalinan, kehilangan darah normal adalah sekitar $300 \mathrm{ml}$, tetapi pada kondisi dimana perdarahan melebihi $500 \mathrm{ml}$ terjadi pada 5$6 \%$ wanita. Pada wanita sehat setelah persalinan normal, prevalensi anemia pada masa nifas 1 minggu pertama adalah $14 \%$ pada wanita yang diberi suplemen zat besi dan $24 \%$ pada wanita yang tidak diberi suplemen (Milman, 2012).

Penting dalam mengatasi anemia pada ibu postpartum. Kondisi bagi ibu dan bayi selama masa pascabersalin, perawatan nifas, laktasi harus menguntungkan bagi keduanya. Ibu nifas dengan anemia dikaitkan dengan gangguan kualitas hidup, penurunan kemampuan kognitif, ketidakstabilan emosi, dan depresi dan merupakan masalah kesehatan yang signifikan pada wanita usia reproduksi (Milman, 2011).

Di Indonesia, belum ada data resmi angka anemia pada ibu postpartum. Kunjungan tenaga kesehatan pada ibu masa nifas bertujuan untuk memastikan tidak ada perdarahan, memastikan proses involusi uteri berjalan 
dengan baik dan perawatan ibu dan bayi (Sulistyawati, 2010). Pemeriksaan rutin penapisan anemia biasanya diperuntukkan pada wanita hamil.

Diketahui penyebab anemia paling sering adalah kekurangan zat besi. Kekurangan zat besi merupakan gangguan kekurangan gizi paling umum pada wanita masa reproduksi. Setelah kehamilan normal dan kelahiran, tanpa kondisi defisiensi zat besi, kebutuhan zat besi yang diserap menurun sampai kehilangan zat besi $0,8 \mathrm{mg} / \mathrm{hari}$ dan ditambah kehilangan zat besi karena menyusui 0,3 mg/hari (Milman, 2012). Kebutuhan zat besi ini harus dipenuhi.

Selain zat besi, terapi untuk anemia adalah asam folat. Asam folat merupakan pendukung zat besi. Asam folat diberikan untuk kerja sel. Defisiensi asam folat menyebabkan kerusakan kromosom, yaitu menginduksi untaian DNA istirahat dan hipometilasi pada gen p53, menyebabkan rendahnya kadar folat dan tinggi hemosistein sehingga penurunan fungsi kognitif (Habib, 2012).

Terapi lain untuk penanganan anemia selain pemberian zat besi adalah cyanocobalamin atau vitamin B12. Vitamin B 12 berperan dalam pembentukan hemoglobin dan metilasi gen. hemoglobin terdiri dari heme dan globin. Untuk pembentukan heme diperlukan kerja vitamin B12. Vitamin B12 membantu aktifitas genetik dengan mengontrol metilasi gen, yaitu menambah atau mengurangi gugus metil DNA. Defisiensi vitamin B12 dalam jangka yang panjang menyebabkan gangguan kognitif yang buruk (O’Leary, 2010).

Pemberian tablet $\mathrm{Fe}$ penting untuk ibu postpartum. Pemerintah memprogramkan bahwa ibu postpartum diharapkan mendapat tablet Fe sebanyak 40 tablet, tanpa mempertimbangkan kadar haemoglobin (Kemenkes, 2012). Namun data mengenai penatalaksanaan anemia pada ibu postpartum masih terbatas.

\footnotetext{
Metode

Penelitian ini adalah penelitian quasi eksperimental dengan rancangan pretest posttest design. Dilakukan pretest yaitu pemeriksaan kadar $\mathrm{Hb}$ awal sebelum suplementasi dan posttest yaitu pemeriksaan kadar $\mathrm{Hb}$ setelah suplementasi. Responden dalam penelitian ini berjumlah 40 ibu postpartum yang anemia, yaitu kadar $\mathrm{Hb}<12 \mathrm{mg} / \mathrm{dL}$, diperoleh dari Bidan Praktek Mandiri di Kota Pematangsiantar dan sekitarnya. Responden dibagi dua kelompok, yaitu ibu postpartum anemia yang diberi suplementasi Fe dan dikombinasi asam folat dan vitamin 12 dan ibu postpartum anemia yang diberi Fe saja. Pemeriksaan kadar Hb dilakukan pada ibu postpartum hari ke-4, metode yang digunakan digital dengan alat Quick Cek. Pemberian suplementasi bila ibu mengalami anemia. Setelah pemeriksaan kadar $\mathrm{Hb}$, ibu diberi suplementasi untuk tujuh hari, penjelasan mengenai cara mengkonsumsi suplemen dan jadwal pemberian suplemen berikutnya. Suplemen diberikan selama 28 hari. Tiap minggu, subjek penelitian diwawancara dengan kuesioner food recall untuk mengetahui asupan makanan yang dikonsumsi ibu selama penelitian.
}

\section{Hasil}

Penelitian dengan judul "Pengaruh suplementasi tablet Fe, Asam Folat, dan Vit. B12 terhadap peningkatan kadar Hemoglobin pada ibu postpartum di Kota Pematangsiantar dan sekitarnya" telah dilaksanakan mulai Mei sampai September 2016. Subjek penelitian merupakan ibu postpartum berjumlah 40 orang yang anemi (kadar $\mathrm{Hb}$ $<12 \mathrm{mg} / \mathrm{dL}$ ). Bila ibu anemia diberi suplementasi. Pengukuran kadar $\mathrm{Hb}$ dilakukan pada hari ke-4 (Hb awal) dan hari ke-32 (Hb akhir) pada ibu postpartum dengan menggunakan alat digital Quick Cek. Karakteristik subjek penelitian terdiri dari usia, paritas, dan asupan makanan (Tabel 1).

Tabel 1 Distribusi Karakteristik Ibu Post partum di Kota Pematangsiantar dan sekitarnya Tahun 2016

\begin{tabular}{llccc}
\hline No & Variabel & $\begin{array}{c}\text { Kelompok A } \\
\text { ( tablet Fe) } \\
\text { n=20 }\end{array}$ & $\begin{array}{c}\text { Kelompok B } \\
\text { ( tablet Fe+ } \\
\text { Asam folat+ } \\
\text { B12) }\end{array}$ & $\boldsymbol{p}$ \\
& & \multicolumn{3}{c}{$\begin{array}{c}\text { n= 20 } \\
\text { Rerata } \pm \text { sb }\end{array}$} \\
\hline & & Rerata \pm sb & $29,35 \pm 5,14$ & 0,79 \\
\hline 1 & Umur & $28,95 \pm 4,25$ & $2,65 \pm 1,19$ & 0,84 \\
2 & Paritas & $2,60 \pm 1,14$ & $2845 \pm 166,14$ & 0,00 \\
3 & Asupan & $2748,75 \pm$ & 2845 \\
& Makanan & 138,24 & & \\
\hline
\end{tabular}

Berdasarkan Tabel 1 menunjukkan bahwa berdasarkan rerata umur responden pada kelompok A adalah 28 tahun sedangkan rerata umur responden kelompok B adalah 29 tahun. Berdasarkan rerata paritas pada kedua kelompok adalah paritas 2. Pada variabel asupan makan rerata kelompok A didapat 2748,75 kal dan pada kelompok B sebesar $2845 \mathrm{kal}$.

Setelah dilakukan pengukuran kadar $\mathrm{Hb}$ sebelum dan sesudah suplementasi diperoleh adanya kesignifikan antara hasil $\mathrm{Hb}$ awal pada kelompok A adalah 10,56 dan $\mathrm{Hb}$ akhir ( $\mathrm{p}$ value 0,005 ). Berarti terdapat peningkatan yang bermakna suplementasi tablet fe terhadap kadar $\mathrm{Hb}$ akhir pada kelompok responden A (Tabel 2).

Tabel 2 Perubahan Kadar Hb pada Ibu Postpartum kelompok A (Tablet Fe) di Kota Pematangsiantar dan sekitarnya Tahun 2016 Variabel n Rerata \pm sb Perbedaan IK 95\% $p$ Rerata \pm sb

Hb awal 20 $10,56 \pm 0,77 \quad 1,81 \pm 0,73 \quad$ l,46 - 2,15 0,005 Hb akhir $20 \quad 12,37 \pm 0,73$

Ket. Uji T berpasangan

Berdasarkan tabel 2 diperoleh pengukuran kadar $\mathrm{Hb}$ sebelum dan sesudah suplementasi pada kelompok B ditemukan hasil $\mathrm{Hb}$ awal adalah 10,65 dan $\mathrm{Hb}$ akhir pada kelompok B sebesar 13,15. Berarti terdapat perbedaan kadar $\mathrm{Hb}$ awal dengan kadar $\mathrm{Hb}$ akhir pada kelompok responden $\mathrm{B}$. 
Tabel 3 Perubahan Kadar Hb pada Ibu Postpartumkelompok B (Tablet Fe+Asam Folat dan B 12) di Kota Pematangsiantar dan sekitarnya Tahun 2016

\begin{tabular}{lcccc}
\hline Variabel & $\mathbf{n}$ & $\begin{array}{c}\text { Median } \\
\text { (Minimum - } \\
\text { Maximum) }\end{array}$ & Rerata \pm sb & $\boldsymbol{p}$ \\
\hline Hb awal & 20 & $10,65(8,3-11,6)$ & $10,26 \pm 1,03$ & 0,00 \\
Hb akhir & 20 & $\begin{array}{c}13,15(10,6- \\
14,7)\end{array}$ & $13,09 \pm 0,81$ & \\
& \multicolumn{4}{c}{} \\
\hline
\end{tabular}

Ket. Uji Wilcoxon

Hasil pemeriksaan $\mathrm{Hb}$ awal pada masing- masing kelompok responden diperoleh bahwa tidak terdapat perbedaan. Dengan rerata $\mathrm{Hb}$ awal kelompok A adalah 10,56 sedangkan rerata $\mathrm{Hb}$ awal kelompok B sebesar 10,26 (Tabel 4)

Tabel 4 Perbandingan Kadar $\mathrm{Hb}$ awal pada Ibu Post partumkelompok A (Tablet Fe) dan kelompok B ( Tablet Fe+Asam Folat dan B 12 ) di Kota Pematangsiantar sekitarnya Tahun 2016

\begin{tabular}{lcccc}
\hline Variabel & $\mathbf{n}$ & $\begin{array}{c}\text { Median } \\
\text { Minimum - } \\
\text { Maximum) }\end{array}$ & Rerata \pm sb & $\boldsymbol{p}$ \\
\hline $\begin{array}{l}\text { Hb awal } \\
\text { kelompok A }\end{array}$ & $10,5(8,9-11,6)$ & $10,56 \pm 0,77$ & 0,58 \\
$\begin{array}{l}\text { Hb awal } 20 \\
\text { kelompok B }\end{array}$ & $\begin{array}{c}10,65(8,3- \\
\text { Ket. Uji Mann Whitney }\end{array}$ & $10,26 \pm 1,03$ & \\
\hline Key & & &
\end{tabular}

Berdasarkan tabel 5 dibawah ini didapat adanya peningkatan yang signifikan ( $p$ value 0,001 ) antara perbedaan kadar $\mathrm{Hb}$ akhir pada kedua kelompok.Dimana hasil pengukuran kadar $\mathrm{Hb}$ responden lebih tinggi pada kelompok B (Suplementasi tablet Fe, Asam Folat dan B 12) dengan rerata $13,09 \mathrm{mg} / \mathrm{dL}$ sedangkan pada kelompok A (suplementasi tablet $\mathrm{Fe}$ ) dengan jumlah rerata adalah $12,37 \mathrm{mg} / \mathrm{dL}$.

Tabel 5 Peningkatan Kadar Hb akhir pada Ibu Post partumkelompok A (Tablet Fe) dan kelompok B (Tablet Fe+Asam Folat dan B 12) di Kota Pematangsiantar dan sekitarnya Tahun 2016

\begin{tabular}{|c|c|c|c|c|}
\hline Variabel & $\mathbf{N}$ & $\begin{array}{c}\text { Median } \\
\text { (Minimum - } \\
\text { Maximum) }\end{array}$ & Rerata \pm sb & $p$ \\
\hline $\begin{array}{l}\text { Hb akhir } \\
\text { kelompok A }\end{array}$ & 20 & $\begin{array}{c}12,35(10,7- \\
13,9)\end{array}$ & $12,37 \pm 0,72$ & 0,001 \\
\hline $\begin{array}{l}\text { Hb akhir } \\
\text { kelompok }\end{array}$ & 20 & $\begin{array}{c}13,15(10,6- \\
14,7)\end{array}$ & $13,09 \pm 0,81$ & \\
\hline
\end{tabular}

Ket. Uji Mann Whitney

Korelasi asupan makanan dengan perubahan kadar $\mathrm{Hb}$ ibu postpartum di Kota Pematangsiantar diperoleh nilai $r$ sebesar 0,38 pada kelompok A dengan nilai $p$ sebesar 0,09 . Pada kelompok B nilai $r$ diperoleh 0,62 dengan $\mathrm{p}$ value sebesar 0,00 . Berdasarkan nilai tersebut disimpulkan terdapat korelasi yang lemah dan tidak signifikan antara asupan makanan dengan kadar $\mathrm{Hb}$ pada kelompok A. Namun berbeda dengan kelompok B, dimana ditemukan korelasi yang kuat dan signifikan antara asupan makanan dan kadar $\mathrm{Hb}$ (Tabel $6)$.

Tabel 6 Korelasi asupan makanan dengan perubahan kadar Hb ibu postpartum di Kota Pematangsiantar dan sekitarnya Tahun 2016

\begin{tabular}{lccc}
\hline Variabel & & $\begin{array}{c}\text { Kadar Hb } \\
\text { Kelompok A }\end{array}$ & $\begin{array}{c}\text { Kadar Hb } \\
\text { Kelompok B }\end{array}$ \\
\hline Asupan & $r$ & 0,38 & 0,62 \\
& $p$ & 0,09 & 0,00 \\
& $\mathrm{n}$ & 20 & 20 \\
\hline
\end{tabular}

Ket. Uji Korelasi Spearmen

\section{Pembahasan}

Pelaksanaan penelitian dengan judul "Pengaruh suplementasi tablet Fe, Asam Folat, dan Vit. B12 terhadap peningkatan kadar Hemoglobin pada ibu postpartum di Kota Pematangsiantar dan sekitarnya" telah selesai dilaksanakan. Definisi anemia menurut WHO (World Health organization) adalah $<11 \mathrm{mg} / \mathrm{dL}$ untuk ibu hamil dan $<12 \mathrm{mg} / \mathrm{dL}$ untuk ibu tidak hamil (WHO, 2011). Data dari Dinas Kesehatan Kota Pematangsiantar diperoleh tidak ada informasi kadar hemoglobin ibu postpartum di Kota Pematangsiantar.

Karakter responden dalam penelitian ini umumnya berumur 28 - 29 tahun dengan paritas dua. Asupan makanan pada ibu postpartum rata-rata 2748 2845 kal. Penelitian yang dilakukan Muwakidah (2009), subjek penelitian merupakan pekerja di PT Tyfountex Kabupaten Sukoharjo dengan usia rata-rata 34-35 tahun. Asupan makanan pada penelitian Muwakidah mengukur jumlah energy, protein, kadar Fe, Asam Folat, dan Vitamin B12. Sementara pada penelitian ini asupan makanan mengukur total kalori tiap 24 jam.

Adanya peningkatan signifikan antara suplementasi dengan kadar $\mathrm{Hb}$. Pemberian tablet Fe pada ibu postpartum merupakan program pemerintah Indonesia (Kemenkes, 2012). Namun data mengenai pemberian tablet Fe pada ibu postpartum belum ada.

Penelitian Binder, et al (2007), ditemukan peningkatan kadar $\mathrm{Hb}$ setelah suplementasi ferrum pada ibu postpartum yang anemia. Namun pada penelitian Binder, pemberian preparat ferrum melalui intravena. Penelitian Milman (2011) di Denmark, diperoleh kenaikan kadar $\mathrm{Hb}$ menjadi 13,4 mg/dL setelah suplementasi tablet $\mathrm{Fe}$ selama 8 minggu postpartum dibanding kelompok suplementasi placebo.

Penelitian Saddang dkk (2012), didapat adanya kenaikan kadar $\mathrm{Hb}$ setelah pemberian preparat besi antara kelompok pemberian oral dan parenteral. Peningkatan terjadi signifikan setelah hari ke-7.

Tabel 3 pada penelitian ini diperoleh peningkatan signifikan antara suplementasi kombinasi dengan kadar Hb. Penelitian yang dilakukan Dodd (2004), diperoleh ibu postpartum yang anemia akan 
lebih meningkat kadar $\mathrm{Hb}$ jika diberi suplemen kombinasi Fe, Folat, dan Vitamin B12 dibanding Ferrum saja.

Pengobatan anemia yang tradisional, yaitu suplemen Fe saja merupakan penanganan anemia di Indonesia. Ibu yang menyusui memerlukan asam folat karena saat menyusui beresiko kekurangan asam folat (Berti, et al (2012). Saat ini tablet Fe yang ada di masyarakat sudah kombinasi dengan asam folat dan vitamin B12. Proses eritropoeisis (pembentukan darah) yang aktif membutuhkan 3 nutrisi kunci, yaitu folat, cobalamin (vitamin B12), dan besi (Fe) (Greenberg, et al, 2011). Asam folat signifikan membantu peningkatan serum folat dan folat sel darah merah serta homosistein plasma. Asam folat berperan pada reaksi transfer 1karbon, pada sintesis DNA dan RNA, metabolisme asam amino, purin, dan sintesa pirimidin serta pembentukan metilasi dasar.

Diperoleh tidak berbeda kadar $\mathrm{Hb}$ awal pada ibu postpartum kelompok suplemetasi kombinasi dan tidak kombinasi (Fe saja). Paad penelitian ini tidak ada perbedaan karakter subjek penelitian pada masingmasing kelompok, baik umur subjek penelitian, paritas, dan asupan makanan yang rata-rata dengan kalori cukup.

Penelitian ini diperoleh adanya signifikan antara kadar Hb akhir pada kelompok Fe dan kelompok suplementasi kombinasi. Suplementasi kombinasi Fe, asam folat, dan vitamin B12 lebih berpengaruh meningkatkan kadar $\mathrm{Hb}$ dibanding suplemen $\mathrm{Fe}$ saja (Dodd, 2004).

Ditemukan korelasi yang lemah dan tidak signifikan antara asupan makanan dengan kadar $\mathrm{Hb}$ pada kelompok suplementasi Fe saja. Berbeda dengan kelompok suplemetasi kombinasi, diperoleh adanya korelasi yang kuat dan signifikan antara asupan makanan dengan kadar $\mathrm{Hb}$. Berarti asupan makanan berpengaruh pada peningkatan kadar hemoglobin darah.

Asupan makanan pada subjek penelitian ini rata-rata dengan kalori cukup (2700 kal) baik pada kelompok suplementasi Fe saja maupun kelompok suplementasi kombinasi. Namun perbedaan suplementasi berpengaruh untuk peningkatan kadar $\mathrm{Hb}$. Asupan makanan pada subjek penelitian didapat sebagian besar mengkonsumsi teh manis setelah makan setiap hari. Bahkan ada subjek penelitian mengkonsumsi teh $3 \mathrm{x}$ dalam sehari.

Teh hitam dan teh hijau berpengaruh terhadap absorpsi ferrum dan asam folat. Teh hijau dan teh hitam bahkan mengurangi bioavailability asam folat (Alemdaroglu, et al, 2008). Penelitian Shiraishi, et al (2010), ditemukan kadar folat rendah pada subjek penelitian yang mengkonsumsi teh hijau dan teh oolong. Pada teh terdapat senyawa epigallocatechin-3gallate yang kerja folat (antifolat). Namun berbeda dengan penelitian Endoh, et al (2013), teh hijau hanya sedikit mengganggu absorpsi folat.

Peningkatan kadar $\mathrm{Hb}$ lebih tinggi pada kelompok suplementasi kombinasi tablet Fe, asam folat, dan Vitamin B12 dibanding kelompok suplementasi tablet Fe. Asupan makanan berkorelasi dengan peningkatan kadar $\mathrm{Hb}$ pada kelompok suplementasi kombinasi

\section{Daftar Pustaka}

Berhan Yifru, Berhan Asres, Causes Of Maternal Mortality In Ethiopia: A Significant Decline In Abortion Related Death, Ethiop J Health Sci. Special Issue, 2014;

reymann, C; Bian, X M; Blanco-Capito, L R; Chong, C; Mahmud, G; Rehman, R, Expert recommendations for the diagnosis and treatment of iron-deficiency anemia during pregnancy and the postpartum period in the Asia-Pacific region, Journal of Perinatal Medicine, 2011; 39(2):113-121.

de Benoist B, McLean E, Egli I, et al. Worldwide prevalence of anaemia 1993-2005: WHO global database on anaemia, Editors; Geneva: World Health Organisation, 2008

Habib Fawzia Ahmed, Morbidity and Mortality in Anemia, Intessar Sultan and Shaista Salman Taibah University-College of Medicine-Al Madinah Al Munawara Kingdom of Saudi Arabia, (2012), Book 'Anemia', ISBN: 978-953-51-0138-3.

Kemenkes, Buku Pegangan Kader Posyandu, Pusat Promosi Kesehatan, 2012.

O'Leary F, Samman S, Vitamin B12 in Health and Disease, Nutrients, 2010; 2 (3): 299-316.

Vitamin $\mathrm{B}_{12}$ in Health and Disease, Fiona O'Leary and Samir Samman

Milman N, Postpartum anemia I: definition, prevalence, causes, and consequences, Ann Hematol, 2011; 90(11):1247-53.

Milman N, Postpartum anemia II: prevention and treatment, Ann Hematol, 2012; 91:143-154.

Sulistyawati A, Nugraheny E, Buku Ajar Asuhan Kebidanan Masa Nifas, Salemba Medika; 2010.

Ahmed Faruk, Concomitant supplemental vitamin A enchances the response to weekly supplemental iron and folic acid in anemic teenagers in urban Bangladesh, Am J Clin Nutri; 2007:74: 108-15

Alemdaroglu NC, Dietz U, Wolffram S, Langguth HS, Langguth $P$, Influence of green tea on folic acid pharmacokinetics in healthy volunteers: Potential risk of disinished folic acid bioavailability, Biopharm. Drug Dispos; 2008: 29: 335-348.

AlmatsierS, Prinsip Dasar Ilmu Gizi. Jakarta: Gramedia Pustaka Utama, 2001.

Ambarwati, R, dan Wulandari D, Asuhan Kebidanan Nifas, Yogyakarta: Mitra Cendika: 2010.

Bakta IM, Anemia dan Laju Filtrasi Glomerulus Pada Penyakit Ginjal Kronik Pradialisis, J. Penyakit Dalam, 2009; 11 (3): 140-7.

Baliga, Ragavendra, Crash Course Internal medicine. Elsevier Mosby: 2007.

Beard JL, Hendricks MK, Perez EM, Murray-Kolb LE, Berg A, Vernon-Feagans L, Irlam J, Isaacs W, Sive A, Tomlinson M, Maternal Iron Deficiency Anemia 
Affects Postpartum Emotions and Cognition, The American Society for Nutritional Sciences, 2005.

Binder T, Zahumensky J, Feldmar P, Dvorska M, Zmrhalova B, Intravenous treatment of postpartum anemia with trivalent ferrum preparation, Ceska Gynekol, 2007; 27 (3), 169-74.

BreymannC, Bian XM, Capito LRB, Chong C, Mahmud G,Rehman R, Expertrecommendation for iron deficiency anemia during pregnancy and the post partum period in the Asia Pacific region, 2011, Universitas of Zurich.

Dodd J, Dare MR, Middleton P, Treatment for women with postpartum iron deficiencyAnaemia, The Cochrane Library, 2007, Issue 4.

Endoh k, Fenech M, Umegaki K, Green tea is a poor contributor to tissue folate in a folate depletionrepletion rat model, Food and Nutrition Sciences; 2013: 4: 136-143.

Elder L.K, Issues in programming for maternal anaemia, Center for Population, 2000; Health and Nutrition, Bureau for Global Programs, Field Support and Research, U.S.

Gibbs R, Danforth's Obstetrics \&Gynecology, Tenth edition, 2008;55(5 Suppl):178S-84S.

Guyton AC, Hall, Buku Ajar Fisiologi Ilmu Kedokteran, Jakarta: ECG (Ed. 11), 2008.

Johnson-Wimbley, Graham DY, Diagnosis and management of iron deficiency anemia in the $21^{\text {st }}$ century, Therap Adv Gastroenterol, 2011; 4 (3): $177-84$.

Kaushansky, et al., Hematology: Clinical Principles and Applications: 2010.

Kemenkes, Buku Pegangan Kader Posyandu, Pusat Promosi Kesehatan, 2012.

Mansjoer,A., Kapita Selekta Kedokteran, Edisi ketiga Jilid 1 Cetakan Keenam, Jakarta: Media Aesculapius Fakultas kedokteran UI, 2005.

Muwakidah, Efek suplementasi Fe, asam folat, dan vitamin B12 terhadap peningkatan kadar hemoglobin pada pekerja wanita di Kabupaten Sukoharjo, 2009
Milman N, Postpartum anemia I: definition, prevalence, causes, and consequences, Ann Hematol, 2011; 90:1247-1253

Prawirohardjo S, Ilmu Kebidanan, Jakarta: Yayasan Bina Pustaka Sarwono Prawirohardjo, 2005.

Ramakrishnan U, Functional consequences of nutritional anemia during pregnancy and early childhood, Nutritional Anemia, 2001.

Ray, N.K., Iron Deficiency in Indonesia, HKI, Jakarta: 1997.

Riskesda, Laporan Hasil Riset Kesehatan Dasar, Kemenkes, 2013.

Saddang Wahyuni, The effect parenteral (iron dextran) and oral (complex iron polymaktose hydroxide III) administration on erithropoiesis respone in postpartum with iron deficiency anemia, 2012; FK Universitas Hasanuddin.

Shiraishi M, Haruna M, Matsuzaki M, Ota E, Murayama $\mathrm{R}$, Murashima S, Association between the serum folate levels and tea consumption during pregnancy, BioScience Trend; 2010: 4 (5): 225230.

Sudoyo, Buku Ajar Ilmu Penyakit Dalam, Jakarta: Pusat Penerbitan Departemen Ilmu Penyakit Dalam FKUI, 2006.

Suherni, Perawatan Masa Nifas, Yogyakarta : Fitramaya: 2007.

Waryana, Gizi Reproduksi, Yogyakarta: Pustaka Rihana: 2010.

World Health Organization (WHO), Reduction of maternal mortality, A joint WHO/UNFPA/UNICEF/World Bank statement. Geneva: WHO,1999.

WHO, United Nations Children's Fund, United Nations University, Iron deficiency anaemia; Assessment, Preventionand Control; A guide for programmemanagers. Geneva: World Health Organization, 2001.

WHO, Global Database on Anemia, Geneva, 2008.

WHO, The global prevalence of anaemia in 2011, Geneva: World Health Organization; 2015. 